sciendo Порівняльна професійна педагогіка 9(4)/2019 Comparative Professional Pedagogy 9(4)/2019

DOI: $10.2478 /$ rpp-2019-0040

Postgraduate Student, VALERII SOROKA

Oleksandr Dovzhenko Hlukhiv National Pedagogical University Address: 24 Kyivo-Moskovska Str., Hlukhiv, 41400, Ukraine

E-mail: valmortal@gmail.com

\title{
DIGITAL EDUCATION \\ IN THE INTERNATIONAL PEDAGOGICAL DISCOURSE
}

\begin{abstract}
The article analyzes the essence of the concept of "digital education", the way of its formation in the international pedagogical discourse. The modern international tendencies of development of digital education which are shown in the conditions of acceleration of processes of digital transformation of a society and their realization in educational establishments are characterized. An important consequence of the digital revolution is the explosives growth of accessible and potentially useful information in various forms - not only traditionally textual, but also visual, audio. All paper is gradually converted to electronic format. One of the most significant innovations is the active implementation of digital education. The results of the comparative analysis have highlighted a number of major components of the digital education system. It has done the analysis of modern trends, which are today the main ones in the implementation of digital education in different educational institutions. The essence and basic qualities of distance and online learning are revealed. The role and main spectrum of tasks that automated testing in the control of knowledge and skills of education recipients is analyzed. A number of important areas are highlighted, which greatly increase the effectiveness of teaching and at the same time require a revision of traditional approaches to learning using mobile devices. Here are some of the key features of Learning Management Systems (LMS). The technology of adapting computer game techniques to non-game processes and events is discussed to increase the involvement of participants in the educational process. A number of benefits of digital education, combined with adaptive learning and personalization, have been highlighted, which are able to help each educator to achieve an optimal level of intellectual development according to his or her natural abilities and inclinations. It is established that the process of following modern trends and tendencies in the field of digital education will change the traditional plane of problems of education, the process of obtaining education will be wider and more flexible.

Keywords: digital education, educational trends, educational tendencies, digitization, automated testing, learning management system, gamification, adaptive learning.
\end{abstract}

\section{АНОТАЦІЯ}

У статті проаналізовано сутність поняття «цифрова освіта», илях ї̈ становлення міжнародному педагогічному дискурсі. Охарактеризовані сучасні світові тенденції розвитку цифрової освіти, які проявляються в умовах прискорення процесів цифрової трансформачії суспільства та їх реалізація в закладах освіти. Важливим наслідком цифрової револючії є вибухове зростання доступної і потенційно корисної інформації у різних формах - не тільки традиційно текстової, а й візуальної, звукової. Усе паперове поступово переходить в електронний формат. Однією з 
sciendo Порівняльна професійна педагогіка 9(4)/2019 Comparative Professional Pedagogy 9(4)/2019

найбільш значущих новацій є активне впровадження в процес навчання циифрової освіти. Результати порівняльного аналізу дали змогу виокремити ряд основних утворюючих компонентів системи цифрової освіти. Здійснено аналіз сучасних трендів, які є на сьогодні основними в реалізації цифррової освіти в різних закладах освіти. Розкрито сутність та основні якості дистаниійного та онлайн навчання. Проаналізована роль та основні спектри завдань, які вирішує автоматизоване тестування при контролі знань і вмінь здобувачів освіти. Виокремлено ряд важливих напрямків, щзо значно підвищують ефективність викладання $i$ водночас вимагають перегляду традииійних підходів до навчання з використанням мобільних пристроїв. Наведено ряд основних можливостей систем управління навчанням (LMS). Розглянуто технологію адаптаиії комп'ютерних ігрових методів до неігрових прочесів $і$ подій для більшого залучення учасників в прочес освіти. Виділено ряд переваг цифрової освіти у поєднанні з адаптивним навчанням і персоналізацією, щчо здатні надати кожному здобувачу освіти допомогу для досягнення оптимального рівня інтелектуального розвитку відповідно до його природних здібностей $i$ нахилів. Встановлено, що прочес прямування за сучасними трендами та тенденціями в галузі ичиррової освіти призведе до зміни традиційної площчини проблем освіти, процес здобування освіти стане більш ширшим і гнучким.

Ключові слова: циффрова освіта, тренди освіти, світові тенденції освіти, циифровізачія, автоматизоване тестування, система управління навчанням, гейміфікація, адаптивне навчання, міжнародний педагогічний дискурс.

\section{INTRODUCTION}

In recent times, modern society is increasingly moving towards digitization - the widespread adoption in all spheres of activity of the latest generation's technologies (informative, communicative, robotics, artificial intelligence, virtual and augmented realities, etc.). The conservative industry, such as education, does not stand aside from these processes. The strength and significance of these processes is such that we can speak about the global impact of digitization on the form and content of the educational process.

Educational systems in the vast majority of countries of the world were formed in previous technological systems, and for this reason, structurally, functionally and ideologically met the requirements of that time. Back in 1998, D. Hanna (1998) drew attention to the new challenges that digitization creates for education. Later, M. Olsen and M. Peters (2005) examined in detail the mechanism of its influence on forms and methods of teaching. G. Yu. Belyaev (2017) analyzed negative tendencies created by digitization for the education system. V. G. Ivanov, A. A. Kaibijainen and L. T. Miftakhutdinova (2018), in their turn, identified the main ways of necessary changes.

One of the most significant innovations is the active introduction of digital education in the learning process.

\section{THE AIM OF THE STUDY}

Revealing the essence of the concept of digital education and analysis of current trends and trends of its development, which are manifested in the context of accelerating the processes of digital transformation of society and their implementation in educational institutions in the international context.

THEORETICAL FRAMEWORK AND RESEARCH METHODS

A certain affinity between the scientific perspectives of researchers and educators as made it possible to explore and analyze digital education in the context of some of its current trends. Different trends and tendencies of digital education that are implemented in educational institutions today were considered by Yu. V. Bunturi, K. L. Buhaichuk, 
sciendo Порівняльна професійна педагогіка 9(4)/2019 Comparative Professional Pedagogy 9(4)/2019

O. V. Kanyshcheva, V. I. Kovalchuk, N. V. Kuznetsov, I. A. Nagaieva, S. I. Tereshchuk, F. Faiella, B. Ricciardi, M. Kalz, D. Earnesty, H. Peng, S. Ma, G. Shelle, H. E. Kentnor, M. Tabuenca, G. Krull, I. Almarashdeh and others.

The following methods were used for the realization of the research goal: analysis, synthesis, comparison and generalization of knowledge of Ukrainian and foreign teachers, which is a characteristic feature of comparative pedagogy.

\section{RESULTS}

The history of digital education is much shorter than the history of information technology in general. It can be said that today it is a kind of peak of information development, the appearance of which was caused not only by technological but also social transformation, the readiness of society to move away from traditional educational models. Today, classic educational formats are becoming less and less popular, while the number of people using various online resources is steadily increasing (Kovalchuk, 2017).

The beginning of digital education came in 2001, when the Massachusetts Institute of Technology launched the OpenCourseWare project, providing open access to a number of its educational materials and educational programs. If digital learning was nonsystematic by then, it has since been presented as a complete end product. Today it is one of the fastest growing areas. In just 18 years, it has gone from a single institute initiative to several hundred independent online platforms with worldwide reach. There are now more than 11,000 open educational programs that have received over 20 million students (Khan, 2019).

As of early 2019, the global online education market for online technologies has exceeded \$ 50 billion. It can be segmented into several geographical areas. The United States is the largest player, accounting for $53 \%$ of the global digital education market. In second place are Asian countries, which together account for $22 \%$ of the world market. The third major player is the European Union $(16 \%)$. The share of all other countries in the world, including Ukraine, accounts for only $9 \%$ (Pappas, 2019).

The concept of digital education is quite broad. To determine it, we tend to follow the approaches of B.S. Gershunsky on the selection of four aspects of meaningful interpretation of education (Gershunsky, 1998). Education as a value (state, public, personal), as a system (an interconnected set of objects with certain properties: flexibility, dynamism, variability, adaptability, stability, predictability, continuity, integrity), as a process (movement from goals to results), subject-object and subject-subject interactions between learners and teachers and those who learn from one another in certain organizational forms involving a variety of learning tools) as a result (acquisition of literacy, education, professional competentness, culture and mentality). We represent the category of "digital education" in terms of process and outcome.

The concept of digital education should be understood as the process of organizing interaction between teachers and learners on the move from goal to result in a digital educational environment, the main tools of which are digital technologies, digital tools and digital footprints as a result of learning and professional activity in digital format.

Digital tools can be represented by software for managing the educational process for organizing the educational process, submitting educational material, recording professional activities, and accounting for achievements in digital format. Digital footprints - all actions of educators in the online space left as a footprint, including presentations, blogs, discussions in various formats in the distance learning system, video facts and more.

The main constituent components of the digital education system are: digital educational environment, digital processes of organization of educational process, digital 
processes of knowledge testing, digital technologies of learning organization, digital content, digital technologies of interaction, digital resources.

Today, any borders are erased through the Internet, people receive information, regardless of the country, at a convenient time for them. Knowledge is becoming the property of all mankind, not one state. Therefore, digital education has seen a transition from offline to online education.

In educational institutions, as V. I. Kovalchuk notes, this trend is realized through the use of distance learning or more modern online learning. Yes, most educational institutions introduce elements of distance learning, such as working with gifted children or providing counseling. The choice of remote platforms or open resources depends on the readiness for such activity of the teaching staff of the educational institution (Kovalchuk, 2017).

In general, distance learning and online learning have a lot in common and are a process of gaining new knowledge and skills. The concept of "distance learning" indicates that there is a distance between the educational recipients and the teacher. "Online learning" means that a topic is learned through an internet connection. That is, the teacher and the educational gainer are also distant from each other. At present, these concepts differ only in their age and possibly frequency of use. Otherwise, they are almost identical and have the following qualities (Kentnor, 2015): individual pace of study, flexible schedule, mobility.

But in such accessibility, there is a downside. Coursera, for example, is a great platform for online education, but according to statistics, only $2 \%$ of educational gainers complete courses by the end. Such statistics are depressing. At the same time, only online education allows you to work with the most up-to-date information and the best professionals in own field (Bersin, 2019).

Another and very relevant trend in digital education today is the reduction of time for education. The less time is spent, and the sooner the opportunity to put the knowledge gained into practice, the sooner the education recipient becomes a qualified specialist and will be able to be proud of real results, not a diploma "on the shelf".

The development of technology, productive forces and society creates new challenges for citizens and corporations, cities and countries. To meet these challenges, we need comprehensive training for effective work in the new environment, which can provide quality education. Globalization has become an effective factor in the development of civilization, the economy and education. Education cannot be restricted to training specialists for the local or national labor market. In fact, the whole world is open to students, so the need to ensure their competitiveness becomes a strategic task of all educational institutions. Appropriate educational programs are required to accomplish this task.

Digital education trends enable the rapid development of relevant educational programs. A team of teachers practitioners can develop a full-time program in a short time and implement it. In addition, the rapid response to changes in the digital industry will help keep it relevant (Kovalchuk, 2016).

Improving the quality of education is possible through the use of innovative forms of teaching and control of student's success. Elements of digital education are actively used in checking the quality of learning. Now the tests and control works do not need to be checked by the teacher - the program does it for him.

That automated testing can be used to solve a wide range of tasks (Nagaeva, 2013):

- testing and control of students' knowledge in different disciplines;

- conducting tests on curatorial hours (psychological, sociological, logical, identifying the points of view of a group of students); 
sciendo Порівняльна професійна педагогіка 9(4)/2019 Comparative Professional Pedagogy 9(4)/2019

- recertification of employees;

- determination of the level of preparation of pupils in schools on a number of disciplines and psychological tests, including vocational guidance;

- conducting polls at competitions, conferences and competitions;

- control of theoretical knowledge and practical skills of teachers acquired in the process of advanced training;

- control of knowledge of part-time students and distance or online forms of study.

Digital education uses a number of tools that can be divided into three groups:

1. Tool software for creating e-learning materials.

2. Platforms for posting materials (providing access to these materials) and accounting for education recipients.

3. Platforms for interactive interaction of participants in the educational process (webinars, forums, chats, social networks).

These instruments can be presented as separate software products and partially implemented in one of them. It is logical that their integration takes place around the material placement platform. It can be presented online, allowing participants in the educational process to receive e-learning through a single window (Almarashdeh, 2016). This platform is called the Learning Management System. It just so happens that these systems are most commonly used for distance learning or for supporting the educational process remotely.

As noted by D. S. Walker, J. R. Lindner, T. P. Murphrey, K. Dooley, the Learning Management System (LMS) is a network platform that allows you to:

- to place electronic educational material of different formats;

- differentiate access to training material;

- to control the progress of the study of the material and the execution of tasks;

- to organize interaction of participants of educational process by means of network communications;

- develop e-learning material.

There are a lot of smart things around us lately, from smartphones and watches to cars and homes. A new level of communication and management of the educational process is ensured through the use of mobile devices for communication between participants in the educational environment. Now having just a smartphone already lets you study anywhere.

Researchers such as: G. Krull, J.M. Duart, B. Tabuenca, M. Kalz, H. Drachsler, M. Specht highlight one of the current trends in digital education in the use of mobile learning, which requires a new look at the teaching process from a methodological point of view. The analysis of the results of observations on learning using mobile devices has highlighted a number of important areas that significantly increase the effectiveness of teaching and at the same time require the revision of traditional approaches to learning: individualization of learning; quick feedback; effective use of study time; continuity of the educational process; a qualitatively new level of management of the educational process (Krull, 2017).

Another trend in modern digital education is gamification, a technology that adapts computer game techniques to non-game processes and events to better engage participants in the educational process.

The goal and expected result of gamification is to change the habitual behavior of the audience involved in educational activities. At the same time, its content remains unchanged, but it is structured in some way, which increases the motivation to solve the 
task, and also increases the time of commitment to this task (Buhaichuk, 2015). The very process of gamification consists of a set of measures that can be applied both in full and in part. Today, gamification is a new way of organizing learning that has tremendous pedagogical potential (Faiella, 2015). The inherent gamification of mechanics allows one to launch the same higher level of activity, which is the root cause, the source of activity of a person having a creative character, to stimulate subjective activity, but not to bring the learner out of reality. In other words, this method allows to make education not boring and exciting.

Foreign researchers: R. Alsawaier, D. Dicheva, S. O'Donovan, M. Mak, C. Garland, A. Darejeh, S. Salim, F. Faiella, M. Ricciardi, J. Mart-Parreo hold that gamification can be a powerful tool to acquire knowledge and can foster important skills such as problem solving, collaboration and communication. But some researchers argue that gamification disrupts learning with a purposeful distraction, adds unnecessary stress, and fails to address the specific pedagogical needs of education seekers.

A major tendency in digital education is adaptive learning, which is able to provide each educational gainer help to achieve an optimal level of intellectual development according to his or her natural abilities and inclinations (Shelle, 2018). It is considered as a way of teaching that provides adaptation to the individual characteristics of students.

Digital education, combined with adaptive learning and personalization, has several advantages (Peng, 2019), in particular:

- provides educational gainers with ample opportunity to freely choose their own learning trajectory of mastering a particular topic;

- provides for a differentiated approach based on the fact that different personalities have different experience and level of knowledge on a particular topic and each applicant learns the subject matter material according to this level of knowledge and depends on his or her individual type of perception and pace of learning;

- increases the efficiency and objectivity of control and evaluation of learning outcomes;

- includes diagnostic control of mastering the topic and adjusting the trajectory of study according to individual characteristics;

- promotes individualization of learning activities (differentiation of the pace of learning, complexity and type of learning tasks);

- increases cognitive activity;

- promotes the development of productive, creative functions of thinking and growth of individual abilities of the educational recipients; with the teacher.

- creates conditions for partnership and cooperation of the educational recipients

\section{CONCLUSIONS}

Modern society is developing in the direction of intellectualization, so in these conditions there is a need to change the pedagogical paradigm and pedagogical technologies. One of the leading tasks is to create a theory of education that must overcome the limitations of knowledge. Particularly important role here is the innovative activity of digital technology and productive thinking. And following the current trends and tendencies in the digital education will change the traditional plane of education problems, the process of education will be wider and more flexible.

Further attention, research and analysis merit the future development tendencies in digital education. Already, some educational institutions and online training sites are using technologies such as, STEAM education, virtual and augmented reality, as well as elements 
sciendo Порівняльна професійна педагогіка 9(4)/2019 Comparative Professional Pedagogy 9(4)/2019

of artificial intelligence. These technologies, in our opinion, will be the first in the field of digital education of the future.

Modern society is developing in the direction of intellectualization, so in these conditions there is a need to change the pedagogical paradigm and pedagogical technologies. One of the leading tasks is to create a theory of education that must overcome the limitations of knowledge. Particularly important here is the innovation of digital technology and productive thinking. Following the current trends and tendencies in the digital education will change the traditional plane of education problems, the process of education will be wider and more flexible.

\section{REFERENCES}

1. Almarashdeh, I. (2016). Sharing instructors experience of learning management system: A technology perspective of user satisfaction in distance learning course. Computers in Human Behavior, 63, 249-255.

2. Bersin, J. (2019). The Disruption of Digital Learning: Ten Things We Have Learned. Retrieved from https://joshbersin.com/2017/03/the-disruption-of-digital-learningten-things-we-have-learned/.

3. Buhaichuk, K. L. (2015). Heimifikatsiia u navchanni: sutnist, perevahy, nedoliky. Proceedings of the Dystantsiina osvita Ukrainy 2015 (Ukraine, Kharkiv, 19-20 November, 2015). Kharkiv: HADI.

4. Faiella, F., \& Ricciardi, M. (2015). Gamification and Learning: A Review of Issues and Research. Journal of e-Learning and Knowledge Society, 11 (3), 1-12.

5. Gershunsky, B.S. (1998). Filosofija obrazovanija dlja XXI veka (V poiskah praktiko-orientirovannyh obrazovatelnyh koncepcij). Moscow: Moskovskij psihologosocialnyj institut.

6. Kentnor, H. E. (2015). Distance education and the evolution of online learning in the United States; curriculum and teaching dialogue. Information Age Publishing, Charlotte, 17 (1-2), 21-34.

7. Khan, Z. (2019). Five Digital Trends That Will Shape Education In 2019. Retrieved from https://elearningindustry.com/digital-trends-in-2019-shape-education-5.

8. Kovalchuk, V. (2016). High education system challenges in the context of requirements of labour market and society. Scientiic letters of academic society of Michal Baludansky, 88-90.

9. Kovalchuk, V. I. (2017). Tendentsii rozvytku osvity v epokhu informatsiinoho suspilstva. Stratehii intensyfikatsii vyshchoi humanitarnoi osvity v Ukraini ta krainakh YeS, $7-134$.

10. Kovalchuk, V. I. (2018). Zastosuvannia tsyfrovoi pedahohiky v pidhotovtsi maibutnikh fakhivtsiv sfery pidpryiemnytstva. Molodyi vchenyi, 5, 523-526.

11. Krull, G., \& Duart, J. M. (2017). Research Trends in Mobile Learning in Higher Education: A Systematic Review of Articles $(2011$ - 2015). International Review of Research in Open and Distributed Learning, 18 (7). Retrieved from http://openaccess.uoc./ edu/webapps/o2/bitstream/10609/93100/1/researchtrends.pdf.

12. Nagaeva, I. A. (2013). Organizacija jelektronnogo testirovanija: preimushhestva i nedostatki. Internet-zhurnal "Naukovedenie", 18 (5). Retrieved from http://naukovedenie.ru/ PDF/111pvn513.pdf.

13. Pappas, C. (2019). Top 20 eLearning Statistics For 2019 You Need To Know. Retrieved from https://elearningindustry.com/top-elearning-statistics-2019. 
sciendo Порівняльна професійна педагогіка 9(4)/2019 Comparative Professional Pedagogy 9(4)/2019

14. Peng, H., Ma, S., \& Spector, J. M. (2019). Personalized adaptive learning: an emerging pedagogical approach enabled by a smart learning environment. Smart Learning Environments, 6. Retrieved from https://slejournal.springeropen.com/ articles/10.1186/s40561-019-0089-y.

15. Shelle, G., Earnesty, D., Pilkenton, A., \& Powell, E. (2018). Adaptive Learning: An Innovative Method for Online Teaching and Learning. The Journal of Extension, 56 (5). Retrieved from https://joe.org/joe/2018september/a5.php.

16. Tabuenca, B., Kalz, M., Drachsler, H., \& Specht, M. (2015). Time will tell: The role of mobile learning analytics in self-regulated learning. Computers \& Education, $89,53-74$.

17. Tereshchuk, S. I. (2016). Tekhnolohiia mobilnoho navchannia: problemy ta shliakhy vyrishennia. Bulletin of Chernihiv National Pedagogical University. Series: Pedagogical Sciences, 138, 178-180.

18. Walker, D. S., Lindner, J. R., Murphrey, T. P., \& Dooley, K. (2016). Learning management system usage: Perspectives from university instructors. Quarterly Review of Distance Education, 17 (2), 41-50. 